\title{
Resource Transitions and Energy Gain: Contexts of Organization
}

\author{
$\underline{\text { Joseph A. Tainter }}^{1}, \underline{\text { T. F. H. Allen }}{ }^{2}, \underline{\text { Amanda Little }}^{2}$, and $\underline{\text { Thomas W. Hoekstra }}^{3}$
}

\begin{abstract}
Energy gain constrains resource use, social organization, and landscape organization in human and other living systems. Changes in energy gain have common characteristics across living systems. We describe these commonalities in selected case studies involving imperial taxation, fungus-farming ants, and North American beaver, and propose a suite of hypotheses for the organization of systems that subsist on different levels of energy gain. Organizational constraints arising from energy gain predict changes to settlement and organization in postcarbon societies.
\end{abstract}

\section{INTRODUCTION}

Anthropology is perennially concerned with the causes and consequences of human resource transitions. Topics such as the origins of agriculture or the organization of irrigation will always be timely. Today, when energy is again on the public agenda, it is important to anticipate the nature of post-fossil-fuel economies and societies as well as the transition to such systems. We address these matters by describing commonalities between social and biological systems in transitions between different regimes of energy gain and in the organization that such regimes impose.

Whereas energy has been central to ecological research for some time (e.g., Odum 1971, 1983, 1996, Schneider and Kay 1994), energy studies in anthropology have waxed and waned in popularity (e.g., White 1949, 1959, Adams 1975, Hardesty 1977, Winterhalder 1981). Many ecological anthropologists have sought to understand the influences of landscape and energy flows on human land use and sociopolitical organization (e.g., Steward 1955, Lee 1968, Rappaport 1968, Vayda 1974, Binford 2001). In historical research, energy flow has been the domain of both prehistorians (e.g., Thomas 1973, Bettinger 1980, Raish 1992, Kohler and Van West 1996) and those who study historical societies (e.g., Sanders and Price 1968, Adams 1981, Tainter 1988, van der Leeuw 1998). Although ecological or energy approaches may never dominate social or historical research, they are a subfield that seems likely to persist.
Perhaps out of respect for disciplinary boundaries, anthropologists rarely venture to compare human organization with that of other living systems. Such comparisons have generally been the domain of systems theorists (e.g., Miller 1978) or of biophysical scientists who venture into the topic of human organization (e.g., Holling 2001). Following in the path of these generalists, we present the initial results of research on the constraints to organization that arise from energy quality and energy gain in human and certain animal societies. In the case studies that we describe below, the patterns are sufficiently strong to warrant exploring both the generalizations that we offer and the implications of future energy for the organization of the industrial world. We explore these implications in the penultimate section.

\section{ENERGY QUALITY AND ENERGY GAIN}

The late Howard Odum was well known as a pioneering thinker on the relationship of energy to society (e.g., Gunderson et al. 2002). He characterized energy as anything that can be fully converted to heat (Odum 1996:16) and available energy, which he called "exergy," as potential energy that is capable of doing work and being degraded in the process (Odum 1996:13, 16). Although energy and exergy are both fundamental concepts, we are more immediately concerned with the ideas of energy quality and energy gain. Fairly neutral conceptions of energy quality might refer to the chemical improbability of a resource or to the heat content of a fuel. Based on the fact that energy may increase in quality as it is transformed, 
Odum used the term "emergy," formerly called "embedded energy," to indicate the energy of one kind used previously to make a service or product (e.g., Odum 1996:7, 26, 265-266). The emergy of fossil fuels, for example, comprises the energy that previously went into the organisms from which these fuels originate as well as the energy from the chemical and geological processes that transformed dead organisms into coal, gas, or petroleum. During these processes of transformation, energy quantity is lost, but energy quality increases. Odum measured the quality of a resource as the ratio of its emergy over its energy, termed "transformity." Transformity increases with the energy transformations that contribute to the formation of a product (Odum 1996:10-11). For example, coal has higher-quality energy than did the plants that went into its making by virtue of having higher emergy and higher transformity.

The concept and measure of energy quality can be more nuanced than is often realized. Beyond the characteristics of a resource that give it absolute quality, energy is of special interest to social scientists when we view it in context. In a human system, the quality of a resource derives both from its absolute transformity, as just described, and from its utility to a particular sociocultural system. Energy quality is, in this sense, specific to technology and the type of economy. Alexander the Great's soldiers observed burning pools of petroleum in central Asia, but for them oil was not a high-quality resource, nor were these pools of any use except for keeping warm on a cold night. Petroleum is a high-quality fuel today largely because it occurs in liquid form. As a liquid, it can perform more useful work per unit of heat equivalent in today's technologies than can coal. Conversely, when Watt was developing his steam engine, the heat value and liquid form of petroleum were of little use, because the new technologies of that day required wood or coal. Energy quality in a human system varies with context, as it may also in other living systems.

Energy quality is important in our discussion mainly as a contributory factor in energy gain. Energy is an investment, even in its most accessible forms. One expends some energy to gain more (e.g., Odum 1971:124-133). The difference is energy gain. Hall et al. (1972:28) label this the "energy return on investment" (EROI), which they define as:

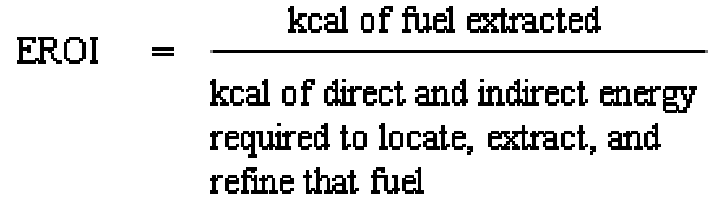

Energy gain, or EROI, varies with the quality (transformity) of a resource deposit and with the efficiency of the technology used to locate, extract, process, distribute, and exploit the resource. As the ease of obtaining or using a resource declines, more energy must be devoted to these activities, causing energy gain to decline. Where an energy budget is substantially constant, allocating more resources to energy production reduces the amount of energy available for other activities. The potential impacts of such a situation on a human system include less leisure time, a lower standard of living, higher taxes, and an increase in childhood mortality. In an animal population, allocating greater effort to energy production may mean less winter fat, increased embryo resorption, lower birth weights, or the like. The diversion of energy from alternative activities to energy production yields the energy opportunity cost (Hall et al. 1992:29). Hall et al. define energy quality in terms of EROI or energy gain, i.e., the amount of energy used to make a unit of natural resources available to society. High-quality resources axiomatically cost less to be brought to use. Because the energy terminology devised by Hall et al. is more widely used in common discourse than that of Odum, their terminology will be used hereafter, although our use of energy quality may also be understood through the concepts of emergy and transformity.

Energy gain has implications beyond mere accounting. It fundamentally influences the structure and organization of living systems, including human societies. Although energy is commonly considered a key component, or even an independent variable, in human cultural evolution (e.g., White 1949, 1959, Steward 1955, Binford 2001), historians have given little attention to the implications of energy gain. This is unfortunate. As will be shown below in the discussion of the Roman Empire, the study of energy gain may increase our understanding of organizational change. Moreover, energy gain allows us to discern commonalities in organizational change between human and other living systems. Comparisons may ultimately emerge with ecosystems, such as estuaries, that are organized around energy pulses (Odum et al. 1995).

High energy gain can arise from using a resource that 
is of high intrinsic quality but untapped, or from technological development that allows an increase in the EROI of a previously used resource. The energy gain of mining deep coal, for example, increased greatly after Watt's engine was widely used (Wilkinson 1973). Conversely, energy gain can decline from exploiting a resource that can yield only small returns on effort under any technology, or from having depleted the most accessible reserves of a once abundant resource. For the sake of illustration, we present high and low gain as polar opposites. They are, of course, the ends of a continuum, and we will undoubtedly find that many interesting questions lie in the intermediate spectrum of that continuum.

Simplifying energy gain into a dichotomy for the purpose of illustration, Table 1 summarizes a set of hypotheses about energy gain and organization. In this table, each numbered row represents a single hypothesis about a particular characteristic related to the nature and consequences of energy gain and the differences between high- and low-gain systems. One purpose of our research is to evaluate how extensively these generalizations can be applied across living systems. It may be that some of these hypotheses pertain to all living systems, whereas others are more restricted in their application. Before illustrating these points in case studies, we amplify the reasoning behind this table.

Hypothesis 1. High-gain systems by definition use a steep energy gradient (Fig. 1) in which there is a great difference between the original state of the resource and its state after use. This difference is less pronounced in a low-gain system. A steep gradient in a useful resource yields a high EROI.

Hypothesis 2. The use of a high-gain resource in a human system is likely to initiate a high-gain phase, exemplified by the role of coal in stimulating the Industrial Revolution (Wilkinson 1973). Where a thermodynamic gradient is shallow, i.e., low gain, the system is less driven and so less constrained. Thus, as seen in Fig. 1, in a low-gain system the direction of flow and system behavior are less predictable (Allen et al. 1999:408, 410, Allen et al. 2001:482). As a result, chance plays more of a role in organizational change. For example, the superiority of the automobile, which has a high gain as long as petroleum is inexpensive, made the demise of the horse and buggy inevitable in wealthy societies. At the same time, the distinctions between makes of automobile are so small that the decision to choose one make over another yields only a small gain, even if one has chosen well. Such choices are less constrained by their gradients and so more subject to chance.

Fig. 1. Characteristics and examples of shallow and steep gradients.
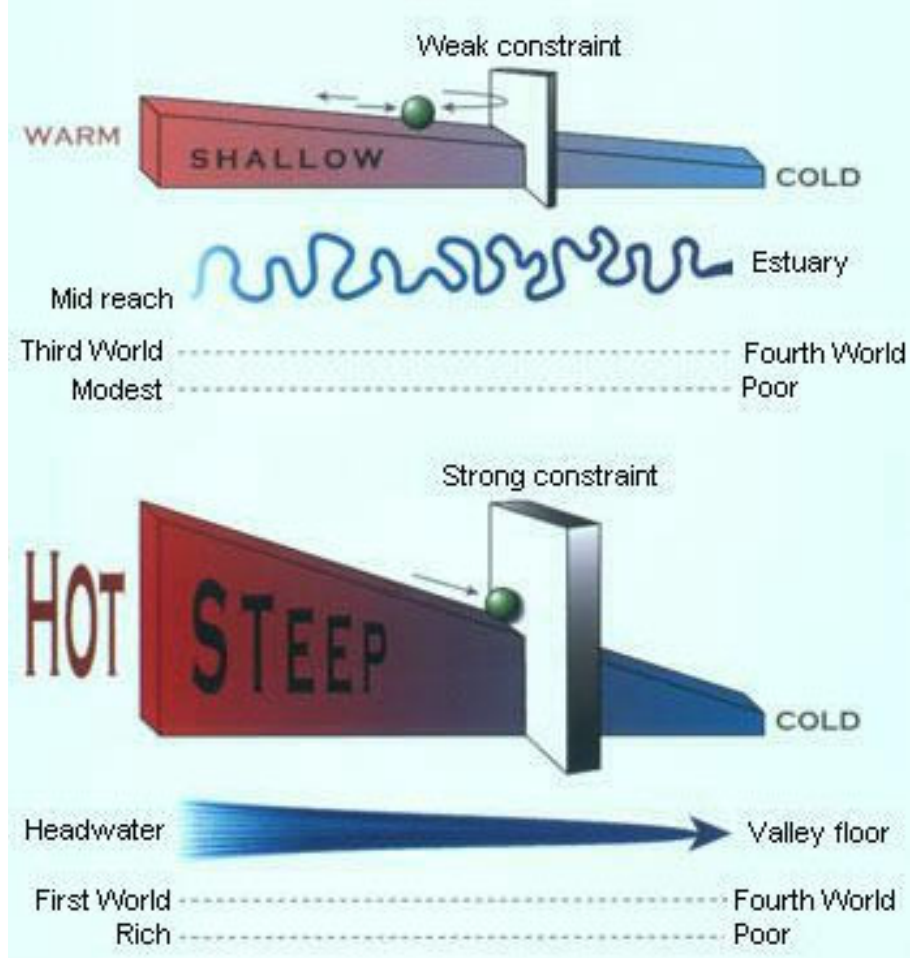

Hypothesis 3. High-quality resources are often those that are just starting to be used, such as irrigation, coal, or petroleum. Low-gain systems are likely to be developed by exploiting the lower-quality reserves of an existing resource or by intensifying the production of a resource already in use. In ancient Mesopotamia, for example, the development of irrigation produced wealth and positive feedback that contributed to the emergence of cities and empires. Later, the expansion of irrigation under the Third Dynasty of Ur (21002000 B.C.) and the Abbasid Caliphate, which lasted from A.D. 750 to 1258 (Adams 1981), transformed production to lower gain to such an extent that average yields per hectare actually declined and both political systems collapsed.

Hypothesis 4. Resources are by definition abundant relative to extractive economics in a high-gain system and scarce in a low-gain system. This is evident in any 
mined resource, where the most productive reserves are used first. Production must then shift to higher-cost reserves, the use of which causes the price of the resource to increase, its availability to decline, and its use to be curbed.

Hypothesis 5. High-gain systems use concentrated energy sources such as the most accessible coal seam or petroleum pool. With a transition to low gain, resource capture becomes more extensive. Resources must be secured from more of the earth's surface to match the gross amount available from a concentrated high-gain source.

Hypothesis 6. Where energy gain is high, resources are likely to be used profligately. As high-quality resources are depleted and costs rise, resource use must become more efficient per capita. At the same time, the high-gain phase facilitates expanded use so that, when the low-gain transition becomes necessary and per capita use becomes more efficient, overall consumption, i.e., overall degradation, may grow. All fossil fuel is of high quality relative to the capture of sunlight through photosynthesis, but within systems based on oil there are also phases of high and low gain. In the United States, for example, the great pools of inexpensive oil in Pennsylvania, Texas, and Oklahoma were depleted profligately to power the wars of the early 20th century, followed by the heavy automobiles of the 1950s and 1960s. Oil is now harder to obtain and cannot be used quite so profligately. Nevertheless, today an even larger fleet of personal automobiles degrades even larger quantities of petroleum, despite the fact that efficiency per vehicle has greatly improved.

Hypothesis 7. A high-gain system can extract resources and organize itself with minimal explicit effort. The steep energy gradient does the work of organization (Fig. 1). In a low-gain system, the demands on the system are great. Humans must replace some of the services formerly provided by a steep gradient. Low-yield resources must be aggregated, which requires costly organization. This is illustrated below in the case studies.

Hypothesis 8. High-gain systems capture large amounts of energy at little cost. EROI is high. Although these systems produce impressive organization, they are notable primarily for highquality energy flow. Low-gain systems may capture even more energy, but, because they must capture it from more extensive sources, organization is required to aggregate resources. The Roman Empire exemplifies this. Late in its history, the Empire greatly expanded its organizational control to amass the dispersed resources needed to survive, as described below.

Hypothesis 9. Not all high-gain systems are of short duration relative to human perceptions of the passage of time. Animal species that rely on high-quality resources, such as some of the fungus-farming ants discussed below, may survive for unknowable numbers of years, and their production system may have existed since the Tertiary. We propose, however, that high-gain systems are often ephemeral relative to their low-gain counterparts. For example, human societies exploiting a high-quality resource tend to burn through it rather quickly. We witness this in economies based on fossil fuels, which can last no more than a few centuries. In contrast, subsistence agriculturalists have been at work for the past 12,000 $\mathrm{yr}$, and no end for them is in sight.

Hypothesis 10. Sudden entrance into a high-gain system may cause a new type of system to emerge, while the previous system continues to exist. Viewing the entire productive system as a hierarchy, a new level emerges at the top, constraining the levels below. For example, industrialism did not supplant agriculture. Our productive system includes both. At the same time, agriculture in wealthy societies is now a subsystem of the industrial sector. That is, agriculture is constrained by industrial technologies and energy sources, so that industrialism acts as a new level at the top of the productive hierarchy. In contrast, low-gain systems tend to solve problems by proliferating components or levels in the middle of a hierarchy. Bureaucracies are a classic example. Both principles are illustrated in Roman history, as discussed below.

Hypothesis 11. High-gain systems are self-organized by their history. Industrial societies, which are organized primarily by their economic and political histories and only minimally by the dictates of annual fluctuations in agriculture, provide a good example of this. In contrast, because low-gain systems depend heavily on resource quantity rather than quality, careful attention must be paid to every variation in the productive system.

Hypothesis 12. High-gain systems are perturbed only by the most extreme environmental disruptions. If disturbed in the context of a steep gradient (Fig. 1), 
they will self-repair or a similar system will emerge to use the high-quality resource. For example, the beaver discussed below will attempt to repair and recolonize high-quality sites if they are removed. In the so-called war on drugs, it does not matter how many Colombian producers are imprisoned. The gradient of illicit drug sales is so steep, i.e., profitable, that new producers will always emerge. In a low-gain system, control can be exerted by manipulating critical parts. Automobile sales, as suggested above, are low gain compared to the initial development of the automobile. Although little can affect the gradient of drug distribution from Colombia to the United States, small changes in pollution regulations can reduce the incentive for overseas automobile producers to remain in the U.S. market.

We illustrate the influence of energy gain on organization in three cases-imperial Roman taxation, fungus-farming ants, and North American beavernoting which of the 12 hypotheses summarized in Table 1 are exemplified in these case studies.

Table 1. Characteristics of high- and low-gain extraction systems.

\begin{tabular}{|c|c|c|}
\hline & High-gain systems & Low-gain systems \\
\hline 1 & Use steep energy gradient & Use shallow energy gradient \\
\hline 2 & $\begin{array}{l}\text { High-quality resource will likely } \\
\text { initiate a high-gain phase }\end{array}$ & Entering a low-gain phase subject to chance \\
\hline 3 & A new type of resource use & Expands an existing resource use \\
\hline 4 & Resources abundant & Resources scarce \\
\hline 5 & Local and concentrated & Extensive \\
\hline 6 & Dissipative and inefficient & More energy degradation, higher efficiency \\
\hline 7 & Minimal demands on system & High demands on system \\
\hline 8 & Impressive in energy capture & Impressive in organization and structure \\
\hline 9 & Brief duration & Lasts significantly longer \\
\hline 10 & New levels at top of hierarchy & New levels in middle of hierarchy \\
\hline 11 & Self-organized & Organized in reference to environment \\
\hline 12 & $\begin{array}{l}\text { Manage through context } \\
\text { or will self-repair }\end{array}$ & Manage by manipulating parts \\
\hline
\end{tabular}

\section{RESOURCE TRANSITIONS}

\section{The Roman Empire}

Our example of an imperial taxation system is the Roman Empire, which is well understood and representative for our purposes. The Romans' early success came from a means of expansion that was fiscally self-perpetuating. Defeated peoples provided the economic basis, and some of the manpower, for further expansion. It was a strategy with high economic returns. By 167 B.C., for example, the Romans were able to stop levying domestic taxes while still expanding the empire. At the same time, the economics of an empire such as the Romans assembled are seductive but illusory. The returns on 
any campaign of conquest are highest initially, when the accumulated surpluses of the conquered peoples are appropriated. Thereafter, the conqueror assumes the cost of administering and defending the province. These responsibilities may last for centuries and are paid for from yearly agricultural surpluses. The fiscal basis of such an empire shifts from accumulated surpluses, which are generally embodied in precious metals, works of art, and population, to current solar energy (Tainter 1988, 1994, 2000). This scenario illustrates hypotheses $1-5,8$, and 9 .

The late Roman Republic is a paradigmatic example of a high-gain phase in which the seizure of accumulated surpluses produced the wealth to finance further campaigns. Nevertheless, this steep gradient so disrupted the political system that republican government was soon terminated with the establishment of a new level at the top of the hierarchy, i.e., that of a permanent emperor and his court. This development signaled both the dissipation of the high-gain gradient and the start of the low-gain but more prolonged imperial phase (hypotheses 1-4, 6, and 8-11).

Once the phase of conquest was complete and the accumulated surpluses spent, the Roman government was financed by agricultural taxes that barely sufficed for ordinary administration. The early empire was administered more by available income than by a planned budget. When extraordinary expenses arose, typically during wars, the precious metals on hand frequently were insufficient to produce the required coinage (hypotheses 4 and 7). Facing the costs of war with Parthia and rebuilding Rome after the Great Fire, Nero began in 64 A.D. a policy that later emperors found irresistible. He debased the primary silver coin, the denarius, reducing the amount of silver in the alloy from 98 to $93 \%$. It was the first step down a slope that resulted two centuries later in a currency that was worthless (1.9\% silver) and a government that was insolvent (Frank 1940, Hammond 1946, Walker 1976, 1977, 1978, Gibbon 1996 [orig. 1776-1788]).

In the half-century from 235 to 284 , the empire nearly came to an end. There were foreign and civil wars almost without interruption. This period witnessed 26 legitimate emperors and perhaps 50 usurpers. Cities were sacked, and frontier provinces were devastated. The empire shrank in the 260s to Italy, the Balkans, and North Africa. By prodigious effort, the empire survived the crisis, but it emerged at the turn of the fourth century A.D. as a very different organization.
In the late third and early fourth centuries, Diocletian and Constantine designed a government that was larger, more complex, more highly organized, and much more costly. They doubled the size of the army, always the major part of imperial costs. To pay for this, the government taxed its citizens more heavily, conscripted their labor, and dictated their occupations (Jones 1964, 1974). These changes illustrate hypotheses $1,3,4,7,8,10$, and 11 .

Diocletian established Rome's first budget, and each year a tax rate was calculated to provide the revenue. The tax was established from a master list of the empire's people and lands, tabulated down to individual households and fields. In an era when travel and communication were slow, expensive, and unreliable, it took substantial organization and personnel just to establish and administer a tax system so minutely detailed. Taxes continued to rise, apparently doubling between 324 and 364 . Villages were liable for the taxes on their members, and one village could even be held liable for another. Tax obligations were extended to widows, orphans, and dowries. In spite of this colossal effort, the government still had to conscript men for the army and requisition services from guilds to meet its needs. Occupations were made hereditary and obligatory. Positions that had once been eagerly sought, such as in city senates, became burdensome (Jones 1964, 1974, Williams 1985) because leading citizens were held responsible for tax deficiencies (hypotheses 4, 6-8, and 12).

The tax system supporting the more complex government and larger army had unforeseen consequences. After plagues decimated the population in the second and third centuries, conditions were never favorable for recovery. There were shortages of labor in agriculture, industry, the military, and the civil service. The tax system of the late empire seems to have been to blame, because the rates were so high that peasants could not accumulate reserves or support large families. Whatever crops were brought in had to be sold for taxes, even if it meant starvation for the farmer and his family. Farmers who couldn't pay their taxes were jailed, sold their children into slavery, or abandoned their homes and fields (hypotheses 3, 4, 7, 11, and 12). Under such circumstances it became unprofitable to cultivate marginal land because too often it would not yield enough for taxes and a surplus, so, despite government edicts, marginal lands were left fallow. In some provinces, up to one-third to one-half of arable land had been deserted by the time of the late 
empire. Faced with taxes, peasants would abandon their lands and flee to the protection of a wealthy landowner, who was glad to have the extra labor. Feudal relations emerged, and, in lieu of peasants, landowners offered vagabonds or even slaves for military service. By 400 A.D., most of Gaul and Italy was owned by fewer than a dozen senatorial families who had the power to defy the government's tax demands (Boak 1955, Russell 1958, Jones 1964, 1974, MacMullen 1976, McNeill 1976, Wickham 1984, Williams 1985).

From the late fourth century the peoples of central Europe could no longer be kept out of Roman territory. The government came to rely almost exclusively on mercenaries from federated peoples. When finally they could not be paid, they overthrew the last emperor in Italy in 476 A.D.

The Roman Empire illustrates a trajectory common among historic empires. The phase of high returns in an imperial system is the immediate postconquest phase during which accumulated surpluses are appropriated, funding extravagant expenditures (hypotheses 1, 2, and 6). This phase is always transitory, quickly replaced by a longer period of lowreturn, hand-to-mouth existence based on taxes (hypothesis 9). Peasant agriculture produces little surplus per capita, and taxes based on it must be collected and aggregated. Taxes are a low-quality resource, because only a relatively small amount can be extracted from each household (hypotheses 1 and 5). Taxes are hard to collect and demand a large infrastructure, but in an agrarian landscape there are a lot of people to tax (hypotheses 6, 8, and 12). Because taxes must be collected from many production units, peasant taxation systems tend to be elaborate and costly (hypotheses 8 and 10). Once an empire enters this phase, the only way to increase revenue quickly is to increase taxes, which may undermine the productive system.

\section{Fungus-farming ants}

The transition from high- to low-gain resource extraction is characteristic of human economic activity. It is also evident in the foraging behavior of other species and in the emergence of species with similar subsistence strategies. For example, there is a cluster of related genera of ants called attoid ants that farm fungi on various organic resources. Widespread throughout the Americas, they are differentiated into 12 genera and 180-200 species (summarized in Weber
1972). Fungus-farming ants probably evolved during the Tertiary in the moist lowlands of South America. Some of the smaller species use primarily insect droppings, especially from caterpillars and woodboring beetles, as a substrate on which to grow the fungus. Ants of the genus Myrmicocrypta use droppings, insect carcasses, and occasional bits of vegetal material that are foraged rather than harvested, the combination varying with season.

The insect droppings that are used as a substrate are of particular interest. Droppings are a comparatively high-quality resource, rich in nutrients and energy. The problem with droppings is that they are also a highly processed resource, several steps away from the sun. High quality as droppings may be, they are in short supply. Foraging for droppings depends on chance finds, and there is no organization by which more may systematically be obtained. This limits the size and organization of the colonies of those species. As a result, Myrmicocrypta average about 100 individuals per colony. They are monomorphic and forage 1.0-1.5 $\mathrm{m}$ from the nest (Hölldobler and Wilson 1990, Jaffe and Hebling-Beraldo 1993, Leal and Oliveira 2000). This situation illustrates hypotheses 1-3, 5, and 11 .

Other fungus-farming ants, such as those of the genus Atta, cut leaves to use as a substrate. Leaf-cutting ant societies are larger and more organized than those that rely on droppings. Colonies have been recorded numbering hundreds of thousands to millions of insects, with highly specialized structure and organization and corresponding polymorphism. Transporting leaves to where they will be used involves long trails through forests or grasslands. These trails often leave a substantial imprint in the ground. Trails have been recorded extending as far as $65 \mathrm{~m}$ from a nest. Although leaf-cutter ants are relatively larger, they carry leaf particles of a size that is small for individuals, but optimal for a foraging party given the constraints of queuing (Weber 1972, Hölldobler and Wilson 1994, Burd 1996, Anderson and McShea 2001). The great quantity of leaves required to produce the same amount of energy per capita as a smaller amount of insect droppings imposes a need for higher organization (hypotheses 1, 3, 5, 8, 10 , and 11).

Among the fungus-farming ants, there appear to have been at least two resource transitions. First, there was the emergence of fungus-farming itself, perhaps derived from fungus growing on collected droppings and the ants' own excrement. It is easiest, and therefore 
common, to start the exploitation of a resource from high-gain material. DNA and morphology suggest that genera such as Mycocepurus, which depend on insect droppings, seeds, and fruits, are closest to the original fungus-farming species, and Atta the farthest from this founding species (Wetterer, Schultz, and Meier 1998). Second, there was the shift from collecting droppings and other materials to cutting leaves, which involved speciation. The first transition depended on the exceptionally high quality of the substrate (hypotheses 1-3). The second transition depended on the leaves as a resource, but was less driven by quality. Leaves are a low-quality resource, abundant but not far removed from the sun. Accordingly, the ants had to become more organized so that they could transport and process massive amounts of this resource (hypotheses 1, 3, 5-8, 10, and 11). E. O. Wilson noted that, "The leaf cutters consume more vegetation than any other comparable numbers of herbivorous species, including mammals, birds, and other kinds of insects" (1986:6). They are so voracious and efficient that they are considered an agricultural pest (hypothesis 12), and can cause millions of dollars in crop losses (Fowler et al. 1986). Like the low-quality taxes of Roman peasants, leaves must be aggregated through high organization and at substantial cost (hypotheses 8 and10).

Earlier we noted that the high-gain/low-gain duality obscures a continuum of intermediate gradations. Species of the genus Trachymyrmex are of interest in this regard (Wetterer, Schultz, and Meier 1998). They appear to be intermediate between Mycocepurus and Atta in many areas, including phylogeny. Trachymyrmex colonies are intermediate in size (230760 individuals). They display slight polymorphism and forage 1.8-2.7 $\mathrm{m}$ from the nest (Weber 1972, Hölldobler and Wilson 1990, Leal and Oliveira 2000). Corresponding to their intermediate position in size, organization, and morphology and on the phylogenetic chart, their foraging is intermediate in energy gain. Trachymyrmex forage primarily on dead vegetation but gather insect droppings during one month near the end of the wet season (Leal and Oliveira 2000). This example illustrates hypotheses $3,5,10$, and 11 .

\section{North American beaver}

More than 30 yr ago, Richard Lee (1968) described how the Kalahari San settle into a grove of nut-bearing mongongo trees and then eat their way outward. North American beaver forage in a similar fashion. At different scales, beaver exhibit resource transitions that involve diet, territorial organization, and population dynamics. One type of resource transition occurs on an annual basis. During the summer, beaver consume primarily herbaceous food, but they depend on bark in the winter (Hall 1960, Svendsen 1980). Herbaceous foods are low in digestively recalcitrant compounds and high in protein (Doucet and Fryxell 1993). Highquality aquatic herbs are typically concentrated in or near water, minimizing search and transport costs. During the summer, beaver are selective in their use of woody browse, consuming from willow only growing tips and leaving the bark. In winter, however, tree bark is the most important resource (Aleksiuk 1970). Woody plants are often dispersed in uplands, making them more difficult to access. The transition between herbaceous and woody resources occurs in the fall, when beaver aggregate and cache woody browse for winter. Colonies that have a supply of overwintering herbaceous tubers will not use low-quality wood (Jenkins 1981). This beaver behavior illustrates hypotheses 1, 4-7, and 9.

Beaver are organized into family colonies, which share and maintain common ponds, dams, and foraging areas in exclusive territories (Barnes and Mallik 1997, Bergerud and Miller 1977). Beaver organize their territories around safe, i.e., water, access to food (Bergerud and Miller 1977). The initial landscape organization is through colonization of a suitable open territory. The food available in such a territory should be accessible by water and high in quality. In response to this high-quality resource, the beaver construct a dam and lodge, forming an impoundment (Johnston and Naiman 1987). Hypotheses 1, 2, 5, and 11 are illustrated by this organization.

Although the switch between high-gain herbaceous vegetation and low-gain woody material is one transition, there is another transition from woody food near a pond to that farther away. After one to several years, a colony consumes most of the woody browse immediately adjacent to the primary impoundment and must transition to more dispersed browse farther from the pond. The animals organize their environment to access this lower-gain resource. Increasing organization involves creating secondary ponds without lodges at less suitable sites upstream and digging canals into the surrounding uplands (Naiman, Johnston, and Kelley 1988). This low-gain extraction has a greater impact on the environment than did the high-gain phase. The animals transport the forage back to the primary impoundment or other feeding station for consumption. Canalization and secondary dam 
construction maintain the established colony by increasing the pool of available resources, but at a cost. These activities are effort-intensive, resulting in lower net returns. Concentrating food resources in centralized locations is necessary to compensate for the low net per capita energy gain for each foraging trip. Marginal returns decrease on the scale of the individual animal, but returns to effort remain high for the colony. When costs become too high and marginal returns too low for the colony, the site is abandoned (hypotheses 1, 3-5, 7, 8, and 11).

Beaver resource capture can be viewed as a hierarchy in which higher- and lower-gain phases of a seasonal and annual nature are nested within longer-term highand low-gain phases. Each site is part of a landscape of similar sites and territories occupied by the regional beaver population. Each colony needs the "sponge" of the larger landscape to provide new territories for its progeny and for itself when forage is depleted (Ulevicius 1999). A high-quality landscape is rich in unsettled territories. Beaver encounter high-quality landscapes upon reintroduction to an area or following a major disturbance, such as fire, that renews food supplies, particularly aspen $20 \mathrm{yr}$ after fire. When there are no predation or hunting constraints, the immense resource of an uninhabited landscape facilitates massive population growth in a short time. Resources inevitably become exhausted as the landscape is saturated, causing the population to crash (Bergerud and Miller 1977). Where a population once had abundant resources in a high-quality landscape, which allowed selectivity, the animals are subsequently forced to depend on the ecosystem's capacity to regenerate those products in a lowerquality landscape. Yearly solar production becomes the constraint. The beaver respond by imposing higher organization on the landscape, engaging in such activities as "block-cutting" willow in a manner not unlike certain forestry practices (Hall 1960), rotating habitats (Busher and Lyons 1999), or harvesting aquatic plants on a sustained-yield basis (Jenkins 1981). This cycle of beaver development illustrates hypotheses 1-9 and 11 .

Resource transitions lend insight into beaver management. For example, manipulating beaver by destroying their dams during a high-quality regionalscale colonization phase will only result in rapid system self-repair, because the same or other beaver will soon attempt to (re)colonize the site. In this case, high-quality resource gradients persist despite the destruction of animals or colonies. To disrupt a specific regional population or colony in a high-quality landscape, one must manage from the context (Allen and Hoekstra 1992, Allen et al. 1999, 2003), which means either destroying the gradient or managing the population level of organization. When landscape quality declines, individual beaver colonies may be more vulnerable to management activities, although the population at large may be less vulnerable because colonies are widely dispersed across a large landscape of low-quality sites (hypotheses 5, 11, and 12).

\section{SUMMARY: ENERGY GAIN AND ORGANIZATION}

The above and other cases exemplify several characteristics common to high- and low-gain extraction in human and other living systems. We presented these characteristics in Table 1 as a set of initial hypotheses. High-gain systems, we argue, tap into steep energy gradients, often in new ways. These systems are impressive not only in their capture of energy but also, and more importantly, in their net return on investment. Because resources are abundant and the demands on the system are minimal, resource use tends to be dissipative and inefficient. The steep energy gradient forces new organization on the system, which causes new levels to emerge at the top of a hierarchy. If such a system is disturbed, the steep energy gradient means that the system will self-repair, or that a similar one will take its place. As just noted, beaver will attempt to repair and recolonize highquality sites after other beaver are removed. Because the high-return resource comes inevitably to be used fully or depleted, however, high-gain phases in human societies and among animals such as beaver tend to be short.

Low-gain phases depend on resources that have a shallower gradient of potential degradation. In a lowgain phase, resources are scarce, and, if the demands on the system are great, it will be vulnerable to instability or will require higher organization. Although net output per capita is low, it is great in the aggregate. Whereas high-gain phases are impressive in their dissipation of energy, low-gain phases are more impressive for their organization. Higher levels of organization and effort are required to maintain a sufficient flow of resources, as seen in the trails of leaf-cutter ants, in beaver canals, or in imperial taxation. In the later Roman Empire, as described above, taxation officials assessed the expected productivity of every parcel of land across all of northwestern Europe and the Mediterranean Basin. 
New levels in a low-gain system, such as bureaucrats or administrators, are inserted into the middle of the hierarchy, which always increases its complexity and costs. Although small energy margins mean that individual producers in such systems are vulnerable to perturbation, the systems themselves may be longlived due to the ubiquity of low-gain resources.

\section{ENERGY GAIN AND FUTURE HUMAN ORGANIZATION}

This framework not only helps us to understand empires, ants, and beavers, but it also suggests clues about our potential future. Since the development of industrialism and economies based on fossil fuels, the world's wealthier nations have been in a high-gain phase. Because high-gain systems use high-quality, concentrated energy, their energy usage is intensive and local. In contrast, low-gain systems, which rely on low-quality energy, must be dispersed in their resource capture and organized correspondingly. Despite the fact that engineers are impressive in their ability to extend the era of high-gain fossil fuel dependence, we know that someday the energy opportunity cost of fossil fuels will reach the point that our dependence on such fuels will diminish (e.g., Campbell and Laherrère 1998). Before that happens, perhaps nuclear fusion will be controlled to the point that it is safe and efficient, providing us with a further source of highquality energy. A primary alternative is the so-called "green" energy sources, including renewables such as wind, wave, and solar. We focus on the consequences of possible future dependence on these.

Renewable energy sources are low gain, yielding little net energy per unit of production compared to fossil fuels. Most renewables depend ultimately on the sun, and the conversion of solar energy to mechanical work is still inefficient (Wayne et al. 1992). Low-gain energy production must therefore be dispersed.

The industrial era was characterized by the application of large amounts of energy and raw materials to solve problems by brute force. In today's so-called information economy, there is much less need to move matter and people. Human settlement can be dispersed. Thus, today we are becoming accustomed to telecommuting, the increased conversion of rural areas into low-density housing, and even the gentrification of rural areas that have traditionally been isolated and impoverished.

The dispersed energy production that would be required by low-gain resources is a good fit with the sort of dispersed settlement pattern that an information economy allows. One scenario for a postcarbon future is dispersed production of low-gain energy by small communities or even individual households. Energy would be captured by small, individual units scattered across the landscape. This is the green energy scenario that many think would be a desirable future, or even preferable today. Unlike many commentators, we take care not to impute morality to preferences regarding energy production systems. Without judgment, therefore, we point out that green energy would encompass its own costs and its own winners and losers. For many people, the transformation would be catastrophic because a decentralized production system would make many infrastructure workers redundant. Urban decay would accompany increased rural settlement. At the same time, new opportunities would emerge in the manufacture and repair of small, dispersed sources of energy production. Hydrogen might be generated as part of local energy-capture systems (Barbir 2001), so that at least some highquality energy would be available for tasks that require it. Many people might prefer such a decentralized existence, but others would find it wrenching. It would require capital investment by each family or community. These investments would be largely redundant, with high energy-opportunity costs, and would not initially enjoy economies of scale. Living standards, as currently defined, would likely decline.

Renewable energy is a popular concept, but there is a certain irony in this. Although environmentalists are quick to blame industry and fossil fuels, the environmental damage done to the world is only partly from industrial sources. The energy used in the industrial world is principally of high quality. It works in a focused fashion with concentrated side effects. In contrast, low-gain agriculture, a highly dispersed activity, is causing a substantial loss of species as well as environmental degradation. The distributed nature of agriculture means that habitat is removed and landscapes are greatly altered. Increased flooding, soil loss, and nonpoint sources of pollution are to a large extent caused by agriculture, as exemplified by the flooding of the Mississippi River in 1993 and the Ohio River in 1997. Although some observers criticize the environmental effects of agribusiness, Third World peasants at their present population levels have an aggregate effect that is substantial, and perhaps comparable. Similarly, the environmental impact of ants that use droppings is minimal compared to those that strip leaves from plants. The former are not considered agricultural pests, whereas the latter are. 
Environmental degradation is greater when the resource is of low quality and distributed but heavily used. Thus, a switch to renewable energy sources might bring, ironically, environmental damage comparable in scale to, or greater than, that caused by the use of fossil fuels. It is also ironic that, although industrialists have not rushed to embrace renewable energy sources, great profits would be made from building the infrastructure needed to capture and concentrate renewable resources. Politicians would be influenced less by road builders and more by businesses that recreate coastlines for wave capture and cover huge tracts of land with solar collectors or wind generators.

\section{CONCLUDING REMARKS}

The concepts of high and low energy gains clarify important organizational differences in human societies and other living systems. The quality of resources and the returns on exploiting them impose organizational constraints that are inescapable. We characterize high- and low-gain systems as polar opposites, but of course there are innumerable systems of resource extraction in between these two extremes. Understanding the organizational requirements of these extraction systems is a rich topic for integrated social and biological research.

It has long been a tantalizing goal to understand commonalities across living systems. The occasional attempts (e.g., Miller 1978, Holling 2001) have so far not generated sustained research programs. In this regard, the potential of studying energy gain is not only that it reveals patterns across living systems, but also that these patterns may clarify potential human energy futures. Thus, the physical science concept of energy gain has the potential to support humanistic interest in the energy transition that the industrial world will inevitably undergo. Energy gain is a uniquely valuable approach to understanding past and future human resource transitions and the ways of life that future energy will both enable and impose.

Responses to this article can be read online at: http://www.consecol.org/vol7/iss3/art4/responses/index.html

\section{Acknowledgments:}

We are pleased to express our appreciation to Tom Abel and John Stepp for the invitation to prepare this paper, to
Tom Abel and four anonymous reviewers for their comments, and to Allen's student Matthew Wallrath for research assistance regarding fungus-farming ants. Amanda Little's research on beaver ecology was conducted as part of the USGS Student Career Employee Program. We thank Kandis Elliot for preparing the illustration used in Fig. 1.

\section{LITERATURE CITED}

Adams, R. M. 1981. Heartland of cities. Aldine, Chicago, Illinois, USA.

Adams, R. N. 1975. Energy and structure: a theory of social power. University of Texas Press, Austin, Texas, USA.

Aleksiuk, M. 1970. The seasonal food regime of arctic beavers. Ecology 51:264-270.

Allen, T. F. H., and T. W. Hoekstra. 1992. Toward a unified ecology. Columbia University Press, New York, New York, USA.

Allen, T. F. H., J. A. Tainter, and T. W. Hoekstra. 1999. Supply-side sustainability. Systems Research and Behavioral Science 16:403-427.

Allen, T. F. H., J. A. Tainter, and T. W. Hoekstra. 2003. Supply-side sustainability. Columbia University Press, New York, New York, USA.

Allen, T. F. H., J. A. Tainter, J. C. Pires, and T. W. Hoekstra. 2001. Dragnet ecology-"Just the facts, ma'am": the privilege of science in a postmodern world. BioScience 51:475-485.

Anderson, C., and D. W. McShea. 2001. Individual versus social complexity, with particular reference to ant colonies. Biological Review 76:211-237.

Barbir, F. 2001. Solar hydrogen energy system-real possibility or Utopia. Pages 3-13 in S. Ulgiati, M. T. Brown, M. Giampietro, R. A. Herendeen, and K. Mayumi, editors. Advances in Energy Studies, Second International Workshop: Exploring Supplies, Constraints, and Strategies. SGEditoriali, Padua, Italy.

Bergerud, A. T., and D. R. Miller. 1977. Population dynamics of Newfoundland beaver. Canadian Journal of Zoology 55:1480-1492.

Bettinger, R. L. 1980. Explanatory/predictive models of hunter-gatherer adaptation. Pages 189-255 in M. B. Schiffer, editor. Advances in archaeological method and theory. Volume 3. Academic Press, New York, New York, USA.

Binford, L. R. 2001. Constructing frames of reference: an analytical method for archaeological theory building using ethnographic and environmental data sets. University of 
California Press, Berkeley, California, USA.

Boak, A. E. R. 1955. Manpower shortage and the fall of the Roman Empire in the west. University of Michigan Press, Ann Arbor, Michigan, USA.

Burd, M. 1996. Server system and queuing models of leaf harvesting by leaf-cutting ants. The American Naturalist 148:613-629.

Busher, P. E., and P. J. Lyons. 1999. Long-term population dynamics of the North American beaver, Castor canadensis, on Quabbin reservation, Massachusetts, and Sagehen Creek, California. Pages 147-160 in P. E. Busher and R. M. Dzieciolowski, editors. Beaver protection, management, and utilization in Europe and North America. Kluwer Academic/Plenum, New York, New York, USA.

Campbell, C. J., and J. H. Laherrère. 1998. The end of cheap oil. Scientific American 278(3):78-83.

Doucet, C. M., and J. M. Fryxell. 1993. The effect of nutritional quality on forage preference by beavers. Oikos 67:201-208.

Fowler, H. G., L. C. Forti, V. Pereira-da-Silva, and N. B. Saes. 1986. Economics of grass-cutting ants. Pages 18-35 in C. S. Lofgren and R. K. Vander Meer, editors. Fire ants and leaf-cutting ants. Westview, Boulder, Colorado, USA.

Frank, T. 1940. An economic survey of ancient Rome. Volume 5: Rome and Italy of the Empire. Johns Hopkins Press, Baltimore, Maryland, USA.

Gibbon, E. 1996 [orig. 1776-1788]. The decline and fall of the Roman Empire. Modern Library, New York, New York, USA.

Gunderson, L., C. Folke, M. Lee, and C. S. Holling. 2002. In memory of mavericks. Conservation Ecology 6(2): 19. [online] URL: http://www.consecol.org/vol6/iss2/art19.

Hall, C. A. S., C. J. Cleveland, and R. Kaufmann. 1992. Energy and resource quality: the ecology of the economic process. University Press of Colorado, Niwot, Colorado, USA.

Hall, J. G. 1960. Willow and aspen in the ecology of beaver on Sagehen Creek, California. Ecology 41:484-494.

Hammond, M. 1946. Economic stagnation in the early Roman Empire. Journal of Economic History, Supplement 6:63-90.

Hardesty, D. L. 1977. Ecological anthropology. Wiley, New York, New York, USA.

Hölldobler, B., and E. O. Wilson. 1990. The ants. Belknap Press, Cambridge, Massachusetts, USA.

Hölldobler, B., and E. O. Wilson. 1994. Journey to the ants. Belknap Press, Cambridge, Massachusetts, USA.
Holling, C. S. 2001. Understanding the complexity of economic, ecological, and social systems. Ecosystems 4:390-405.

Jaffe, K., and M. J. Hebling-Beraldo. 1993. Oxygen consumption and the evolution of order: negentropy criteria applied to the evolution of ants. Experientia 49:587-592.

Jenkins, S. H. 1981. Problems, progress and prospects in studies of food selection by beavers. Pages 559-579 in J. A. Chapman and D. Pursley, editors. Proceedings of the Worldwide Furbearer Conference, Frostburg, MD, August 1980. Worldwide Furbearer Conference, Frostburg, Maryland, USA.

Johnston, C. A., and R. J. Naiman. 1987. Boundary dynamics at the aquatic-terrestrial interface: the influence of beaver and geomorphology. Landscape Ecology 1:47-57.

Jones, A. H. M. 1964. The later Roman Empire, 284-602: a social, economic and administrative survey. University of Oklahoma Press, Norman, Oklahoma, USA.

Jones, A. H. M. 1974. The Roman economy: studies in ancient economic and administrative history. Blackwell, Oxford, UK.

Kohler, T. A., and C. Van West. 1996. The calculus of self-interest in the development of cooperation: sociopolitical development and risk among the northern Anasazi. Pages 169-196 in J. A. Tainter and B. Bagley Tainter, editors. Evolving complexity and environmental risk in the prehistoric Southwest. Santa Fe Institute, Studies in the Sciences of Complexity, Proceedings, Volume 24. Addison-Wesley, Reading, Massachusetts, USA.

Leal, I. R., and P. S. Oliveira. 2000. Foraging ecology of attine ants in a neotropical savanna: seasonal use of fungal substrate in the cerrado vegetation of Brazil. Insectes Sociaux 47:376-382.

Lee, R. B. 1968. What hunters do for a living, or, how to make out on scarce resources. Pages 30-48 in R. B. Lee and I. DeVore, editors. Man the hunter. Aldine, Chicago, Illinois, USA.

MacMullen, R. 1976. Roman government's response to crisis, A.D. 235-337. Yale University Press, New Haven, Connecticut, USA.

McNeill, W. H. 1976. Plagues and peoples. Anchor/Doubleday, Garden City, New Jersey, USA.

Miller, J. G. 1978. Living systems. McGraw-Hill, New York, New York, USA.

Naiman, R. J., C. A. Johnston, and J. C. Kelley. 1988. Alteration of North American streams by beaver. BioScience 38:753-762.

Odum, H. T. 1971. Environment, power, and society. Wiley-Interscience, New York, New York, USA. 
Odum, H. T. 1983. Systems ecology. Wiley, New York, New York, USA.

Odum, H. T. 1996. Environmental accounting: EMERGY and environmental decision making. Wiley, New York, New York, USA.

Odum, W. E., E. P. Odum, and H. T. Odum. 1995. Nature's pulsing paradigm. Estuaries 18:547-555.

Rappaport, R. 1968. Pigs for the ancestors: ritual in the ecology of a New Guinea people. Yale University Press, New Haven, Connecticut, USA.

Raish, C. 1992. Domestic animals and stability in pre-state farming societies. British Archaeological Reports, International Series, Number 579. British Archaeological Reports, Oxford, UK.

Russell, J. C. 1958. Late ancient and medieval population. American Philosophical Society, Philadelphia, Pennsylvania, USA.

Sanders, W. T., and B. J. Price. 1968. Mesoamerica: the evolution of a civilization. Random House, New York, New York, USA.

Schneider, E., and J. J. Kay. 1994. Life as a manifestation of the second law of thermodynamics. Mathematical and Computer Modelling 19:25-48.

Steward, J. H. 1955. Theory of culture change. University of Illinois Press, Urbana, Illinois, USA.

Svendsen, G. E. 1980. Seasonal change in feeding patterns of beaver in southeastern Ohio. Journal of Wildlife Management 44:285-190.

Tainter, J. A. 1988. The collapse of complex societies. Cambridge University Press, Cambridge, UK.

Tainter, J. A. 1994. La fine dell'amministrazione centrale: il collaso dell'Impero Romano in Occidente. Pages 12071255 in J. Guilaine and S. Settis, editors. Storia d'Europa. Volume 2: Preistoria e antichità. Einaudi, Turin, Italy.

Tainter, J. A. 2000. Problem solving: complexity, history, sustainability. Population and Environment 22:3-41.

Thomas, D. H. 1973. An empirical test for Steward's model of Great Basin settlement patterns. American Antiquity 38: $155-176$

Ulevicius, A. 1999. Density and habitats of the beaver (Castor fiber) in Lithuania. Proceedings of the Latvian Academy of Sciences 53B:101-106.

van der Leeuw, S. E., editor. 1998. The Archaeomedes project: understanding the natural and anthropogenic causes of land degradation and desertification in the Mediterranean Basin. Office for Official Publications of the European Communities, Luxembourg.
Vayda, A. P. 1974. Warfare in ecological perspective. Annual Review of Ecology and Systematics 5:21-31.

Walker, D. R. 1976. The metrology of the Roman silver coinage. Part 1: From Augustus to Domitian. British Archaeological Reports, Supplementary Series, Number 5. British Archaeological Reports, Oxford, UK.

Walker, D. R. 1977. The metrology of the Roman silver coinage. Part 2: From Nerva to Commodus. British Archaeological Reports, Supplementary Series, Number 22. British Archaeological Reports, Oxford, UK.

Walker, D. R. 1978. The metrology of the Roman silver coinage. Part 3: From Pertinax to Uranius Antoninus. British Archaeological Reports, Supplementary Series, Number 40. British Archaeological Reports, Oxford, UK.

Wayne, G., C. A. S. Hall, and D. Behler. 1992. Solar energy. Pages 285-319 in C. A. S. Hall, C. J. Cleveland, and R. Kaufmann, editors. Energy and resource quality: the ecology of the economic process. University Press of Colorado, Niwot, Colorado, USA.

Weber, N. A. 1972. Gardening ants, the attines. American Philosophical Society, Philadelphia, Pennsylvania, USA.

Wetterer, J. K., T. R. Schultz, and R. Meier. 1998. Phylogeny of fungus-growing ants (tribe Attini) based on mtDNA sequences and morphology. Molecular Phylogenetics and Evolution 9:42-47.

Wickham, C. 1984. The other transition: from the ancient world to feudalism. Past and Present 103:3-36.

White, L. A. 1949. The science of culture. Farrar, Straus and Giroux, New York, New York, USA.

White, L. A. 1959. The evolution of culture. McGraw-Hill, New York, New York, USA.

Williams, S. 1985. Diocletian and the Roman recovery. Methuen, New York, USA.

Wilkinson, R. G. 1973. Poverty and progress: an ecological model of economic development. Methuen, London, UK.

Wilson, E. O. 1986. The defining traits of fire ants and leafcutting ants. Pages 1-9 in C. S. Lofgren and R. K. Vander Meer, editors. Fire ants and leaf-cutting ants. Westview, Boulder, Colorado, USA.

Winterhalder, B. 1981. Foraging strategies in the boreal forest: an analysis of Cree hunting and gathering. Pages 6698 in B. Winterhalder and E. A. Smith, editors. Huntergatherer foraging strategies: ethnographic and archeological analyses. University of Chicago Press, Chicago, Illinois, USA. 